Asian J. Med. Biol. Res. 2019, 5 (4), 303-315; doi: 10.3329/ajmbr.v5i4.45269

\author{
Asian Journal of \\ Medical and Biological Research \\ ISSN 2411-4472 (Print) 2412-5571 (Online) \\ www.ebupress.com/journal/ajmbr
}

\title{
Article \\ Growth and economic performance of different supplementary feed on female mud crab (Scylla olivacea) fattening in plastic box
}

\begin{abstract}
Kumar Prasun Das ${ }^{1}$, Subrata Mondal ${ }^{1 *}$ and Abdulla-Al-Asif ${ }^{2}$
${ }^{1}$ Department of Fisheries and Marine Bioscience, Faculty of Biological Science and Technology, Jashore University of Science and Technology, Jashore-7408, Bangladesh

${ }^{2}$ Department of Animal Science and Fishery, Faculty of Agriculture, Science and Technology, Universiti Putra Malaysia, UPM Bintulu Sarawak Campus, P.O. Box 396, Jalan Nyabau, Bintulu, Sarawak, Malaysia

*Corresponding author: Subrata Mondal, Department of Fisheries and Marine Bioscience, Faculty of Biological Science and Technology, Jashore University of Science and Technology, Jashore-7408, Bangladesh. E-mail: subrata.fmb.just@gmail.com
\end{abstract}

Received: 19 October 2019/Accepted: 30 November 2019/ Published: 31 December 2019

\begin{abstract}
The present study was conducted to identify low cost feed for female mud crab (Scylla olivacea) fattening practice in plastic box and the effect of different feeds on growth and survival rate of mud crab. A number of 30 adult non-gravid female crabs were reared into rectangular shaped plastic boxes, each box containing one crab. Three types of feed such as Chicken intestine, Tilapia and Apple Snail meat were supplied as feed at $10 \%$ of body weight of the crabs once daily considered as Treatment-1, Treatment-2 and Treatment-3 respectively with 10 replications each to compare the fattening system.. The crabs in plastic boxes were floating into water to fatten for 10 days. Survival rate of crab was found $100 \%, 90 \%$ and $100 \%$ respectively in chicken intestine, tilapia and apple snail meat. In the experiment food conversion ratio (FCR) and specific growth rate in weight $(\mathrm{SGRw})$ were varied significantly among different foods $(\mathrm{P}>0.05)$. Comparative benefit-cost analysis showed that use of chicken intestine as feed in crab fattening attained higher net profit than crab fattening used tilapia and apple snail s feed from 7-12 days fattening period The present study revealed that utilization of chicken intestine as feed for mud crab fattening might be better than any other feeds and cost effective in Bangladesh.
\end{abstract}

Keywords: mud crab; fattening; plastic box; Bangladesh

\section{Introduction}

Bangladesh has a vast area of coastline including 618,780 ha of mangrove tidal flat and 80,000 ha of prime area which is suitable for brackish water aquaculture (Anon, 2003) especially for crab culture. The mud crab fishery is absolutely based on wild catch mainly from the swamps of the mangrove (Hoque et al., 2015; Kaleem et al., 2016) and vast areas of the traditional shrimp ghers along the coastal region of Bangladesh. Its actual culture technique of mud crab has not yet been developed in our country. People of the coastal region follow traditional fattening process to grow crab. Fattening usually requires 7-15 days to complete. Within this time, premature crabs are well fed to develop their gonad fully. Subsequently, there is a great potential of crab culture throughout the coastal area in Bangladesh. Millions of poor fishers, traders and transporters are directly or indirectly dependent on crab fishery in Bangladesh (Zafar and Ahsan, 2006; Hossain et al., 2018; Hossain et al., 2015; Asif et al., 2014; Rahaman et al., 2015; Islam et al., 2017; Leela et al., 2018;). The mud crab was first exported in 1977-78 fiscal year and become a stable business in 1982. Before 1977 it was a virgin stock and the local market was very small. During 2006-07 fiscal year mud crabs has taken the 3rd rank among the fish and fisheries export earnings from Bangladesh. Therefore, the export of live mud crab from Bangladesh has increased many folds in the last decades. Mud crab is popular as a palatable and valued food item globally and 
the most popular and costly sea foods in the South-East Asian countries (Chandra et al., 2012). It also has a good nutritional value. It contains, on a wet weight basis, 15-25 percent protein, 1 percent fat and 2-3 percent minerals (Huq et al., 2015). The mud crab (Scylla sp.) trade, a high-value export fishery encompassing nearly 23 countries throughout the world. China is the single largest crab importer from Bangladesh. Crab is also being exported to Malaysia, Indonesia, Taiwan, Japan, Singapore, Korea, the US, Myanmar and some European countries. Also there is a rising market for mud crab meats as a value added product and frozen soft-shelled mud crab in U.S.A. (Keenan, 1999). Three kinds of crab culture, such as soft shell culture, hard shell culture and fattening of female mud crab are widely practiced in Bangladesh. Soft shell culture is highly labor intensive and thus expensive and unreasonable for most of the coastal farmer. Hard shell culture is comparatively easier but it is a long-time process. Crab fattening is a short time practice and very lucrative. It requires less investment, labor and area which make it affordable for a wide range of farmer. The female with fully grown gonad is opaque while the ones with less developed gonad are transparent and look orange in color. Female crabs with fully grown gonad are called fattened crab. Depot owners won't buy female crabs unless they are full of eggs and meat. A farmer can purchase an empty female with no eggs for 100-150 BDT and sell it when full of eggs and meat after a couple of weeks for 200-250 BDT a piece (Hossain et al., 2018). This is a very quick cultureventure of around 7-15 days; can be done in very small area of ponds. Normally several types of culture techniques are being widely used to culture the crab in south-western part of Bangladesh such as earthen pond culture, pen culture, cage culture etc. However, a new technology is practicing in crab fattening culture at southwest regions of Bangladesh and it is known as the plastic box method. Plastic box method is more effective than cage and pen culture methods since there is no cannibalism, thus survival rate is almost $100 \%$ in plastic box. Plastic box is reusable, cost effective and require less maintenance. This method has an additional advantage to harvest mature crab easily from the plastic box. Therefore, this experiment mainly focuses on fattening of female mud crab by giving three following different feeds that minimize the cost of the farmers. Three feeds were Broiler Chicken Intestine, Tilapia and Apple Snail and it content $11.78 \pm 0.17 \%$ (Jokanovic et al., 2014), $13.66 \pm 2.19 \%$ (Olopade et al., 2016) and $10.67 \pm 0.15 \%$ (Obande et al., 2013 ) crude protein respectively. In this system no cannibalism is occurred and crab can be fattened at demandable size within around 7-12 days providing feeding and other management. In this experiment, female mud crabs were fattened for 10 days. In addition, the present study also pointed out economic performance of female mud crab fattening practice. So far, the present investigation was undertaken to encounter the effect of different food types on female mud crab fattening in plastic box; to find out low cost feed for female mud crab (Scylla Sp.) fattening practice; and to evaluate the economic performance of female mud crab for each feed types during fattening.

\section{Materials and Methods}

\subsection{Study site and periods}

This study was conducted at Bahadurpur village of Kullya union near Budhhata bazar of Assashuni upazila of Satkhira district, Bangladesh during April 22, 2018 to May 1, 2018. The fattening period of female mud crab was 10 days (Figure 1).

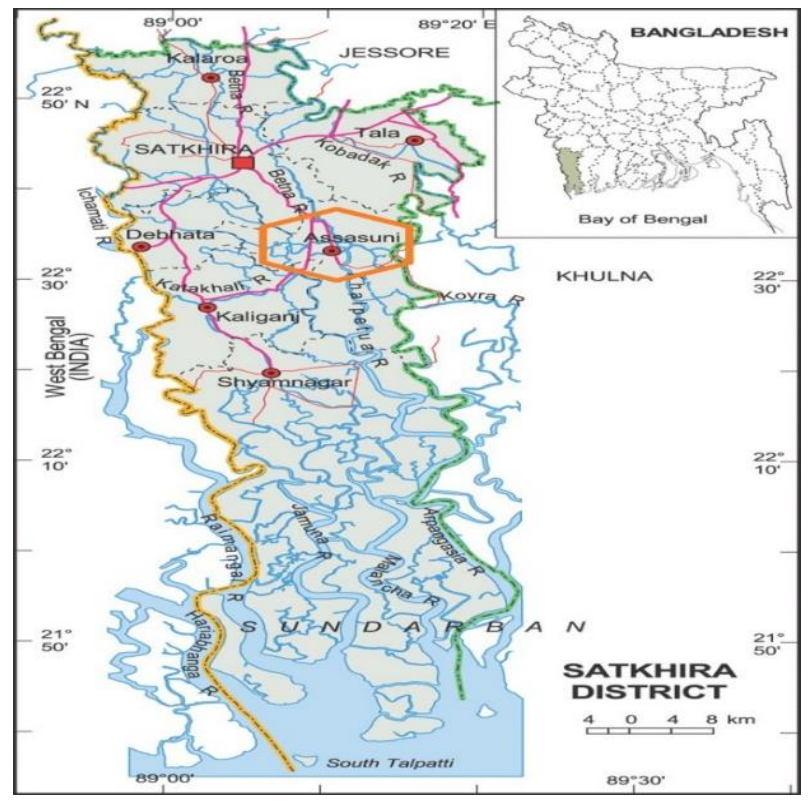

Figure 1. Map of the study area. 


\subsection{Experimental setup and rearing design}

Three types of food (tilapia, snail meat, chicken intestine) were given at $10 \%$ of the body weight. There were 3 treatments in the experiment. Each treatment had 10 replications. 30 pieces of identical plastic box were used for the experimental trial. A total of 30 immature female mud crabs were brought from the local crab collectors (Table 1).

Table 1. Layout of the experiment.

\begin{tabular}{|l|l|l|l|l|}
\hline Treatment no. & Box no. & Food type & Feeding rate & Number of replication \\
\hline Treatment 1 & $1-10$ & Chicken intestine & $10 \%$ & 10 \\
\hline Treatment 2 & $11-20$ & Tilapia & $10 \%$ & 10 \\
\hline Treatment 3 & $21-30$ & Apple snail meat & $10 \%$ & 10 \\
\hline
\end{tabular}

\subsection{Feeding}

Gut content of tilapia, shell of snail and food waste from the broiler chicken intestine were removed before feeding the crab. All food was chopped to match the desired amount for each treatment and was given as live food. Feed was given daily at the around 11:30 AM.

\subsection{Measurement of water quality parameters}

Water quality parameters such as $\mathrm{pH}$, salinity, temperature, $\mathrm{DO}$ were measured during stocking and every day at 11.30 AM during the study period. Water temperature, $\mathrm{pH}$, salinity and $\mathrm{DO}$ were measured by thermometer, $\mathrm{pH}$ test kit $(\mathrm{Bio} \mathrm{pH})$ refracto-meter and titration method respectively.

\subsection{Maturity test and harvesting}

Maturities were tested by traditional light method (sunlight or torch light) after 5 days and continued until gonad of female mud crabs developed fully.

\subsection{Calculation}

\subsubsection{Estimation of survival rate}

Survival rate was estimated in percentage using the formula (SR, \%). The survival rates examined based on Jobling (1995).

\subsubsection{Growth performance}

Growth performance of the mud crab was evaluated using the following parameters average weight gain, percent weight gain, Specific growth rate (SGR), measurement of the increase in carapace width (CW) and total weight gained (TWG) for the different weight groups of crabs was calculated based on Tacon (1990) and De Silva and Anderson (1995).

\subsubsection{Calculation of total production}

The production of each treatment was determined by multiplying average weight $(\mathrm{g})$ gained by the number of crab survived at the end of the experiment. Production was calculated by the following formula,

Total production $=$ Number of crab harvested $\times$ mean final weight $(\mathrm{g})$

\subsubsection{Feed utilization}

The following parameters were used to determine feed utilization by mud crab such as FCR, FCE.

a. Feed conversion ratio $($ FCR $)$

b. Feed Conversion Efficiency (FCE)

$$
\mathrm{FCR}=\frac{\text { Feed fed }(\text { dry weight })}{\text { Live weight gain }}
$$

$$
\mathrm{FCE}=\frac{\text { Live weight gain }}{\text { Feed fed }(\text { dry weigt })}
$$

\subsection{Economic analysis}

To evaluate economic efficiency of the culture system, income and cost was compared. Gross revenue and net return were calculated according to Cholik and Hanafi (1992). 
2.8. Statistical analysis

All data were analyzed using SPSS (v.16) and Microsoft office excel packages (Office 2013). One-way analysis of variance (ANOVA) was applied to find significant differences between treatments with respect to survival rate and growth rates. Pearson's Correlation was done to find out relationship between survival rate and production.

\section{Results and Discussion}

\subsection{Water quality}

\subsubsection{Water temperature}

Throughout the trial period water temperature fluctuated between $28.4{ }^{\circ} \mathrm{C}$ to $32.7{ }^{\circ} \mathrm{C}$ while the highest temperature was documented on April 24, 2018 and the lowest temperature was recorded on April 28, 2018.The mean temperature of water was noted $30.42 \pm 1.29{ }^{\circ} \mathrm{C}$ during the trial period (Table 2 and Figure 2).

Table 2. Water quality parameters variation during mud crab fattening practice.

\begin{tabular}{|l|l|l|l|l|}
\hline Water quality parameter & Maximum & Minimum & Average (average \pm se) & Acceptable range \\
\hline $\mathrm{pH}$ & 8.1 & 7.7 & $7.89 \pm 0.17$ & $4-9$ \\
\hline Salinity (ppt.) & 19.3 & 17.1 & $18.29 \pm 0.71$ & $10-35$ \\
\hline Temperature $\left({ }^{\circ} \mathrm{C}\right)$ & 32.7 & 28.4 & $30.40 \pm 1.21$ & $21-35$ \\
\hline DO $(\mathrm{mg} / \mathrm{l})$ & 8.3 & 7.8 & $8.16 \pm 0.23$ & $>4$ \\
\hline
\end{tabular}

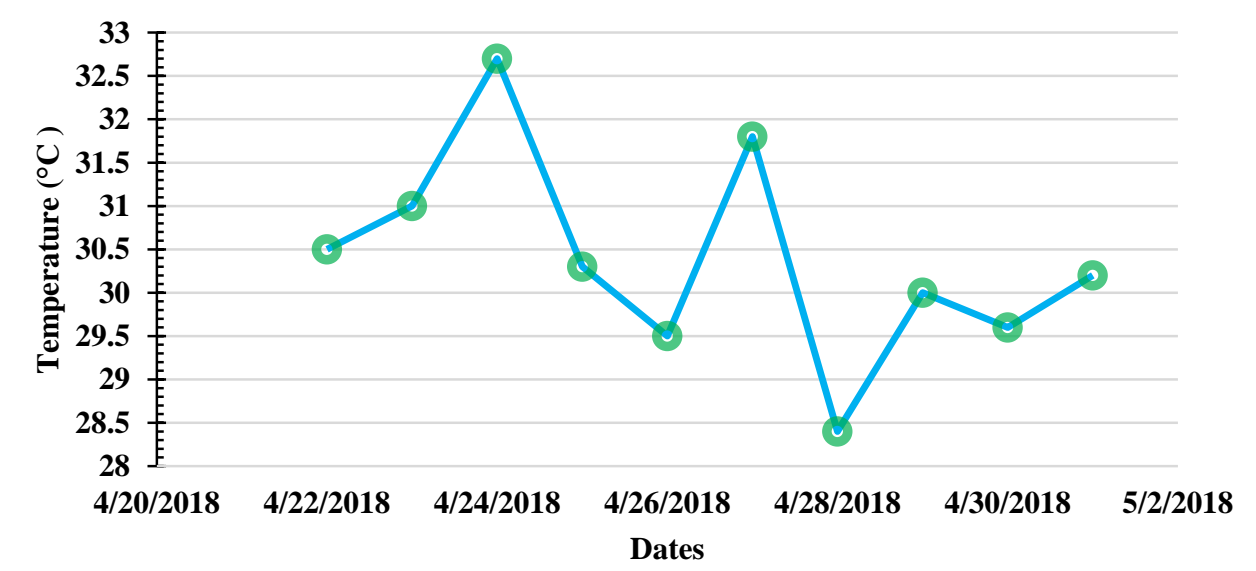

Figure 2. Temperature fluctuation during mud crab fattening practice.

\subsubsection{Salinity}

The salinity of the trial pond water varied between $17.1 \mathrm{ppt}$. to $19.3 \mathrm{ppt}$. Salinity was fluctuated due to rainfall and evaporation by sunlight. The highest value was observed on April 27, 2018 and lowest value was recorded on April 25, 2018. The average value of salinity of water was documented as $18.29 \pm 0.75 \mathrm{ppt}$ (Figure 3).

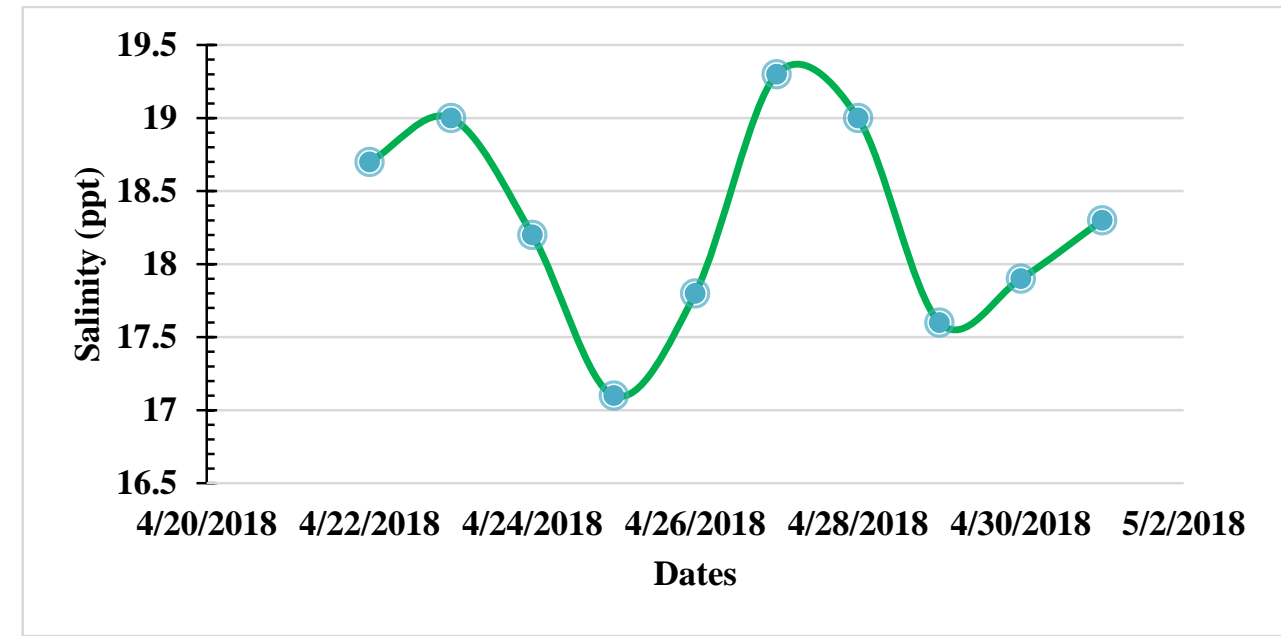

Figure 3. Salinity variation during mud crab fattening practice. 


\subsubsection{Water $\mathbf{p H}$}

The $\mathrm{pH}$ values of trial pond water ranged from 7.5 to 8.5 with a mean value of $7.96 \pm 0.39$. The highest value of pH was recorded on April 29, 2018 and the lowest value of pH was documented on April 23 and 24, 2018 (Figure 4).

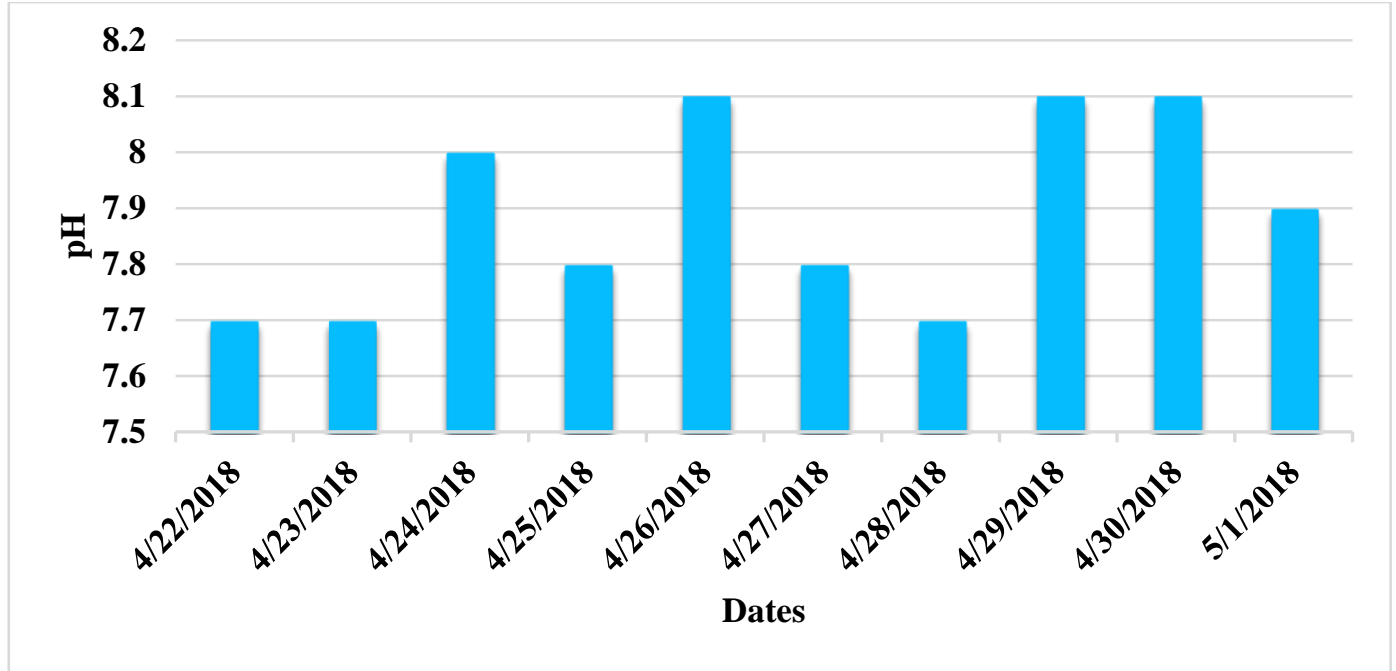

Figure 4. pH variation during mud crab fattening practice.

\subsubsection{Dissolved oxygen}

Dissolved oxygen content of water varied from7.8 mgl${ }^{-1}$ to $8.3 \mathrm{mgl}^{-1}$ during the fattening period. The peak value was documented on April 25 and 26, 2018 and the lowest value was documented on April 28, 2018. The mean value was $8.14 \pm 0.26 \mathrm{mg} / \mathrm{l}$ and the variation of DO were within acceptable range for mud crab fattening (Figure 5).

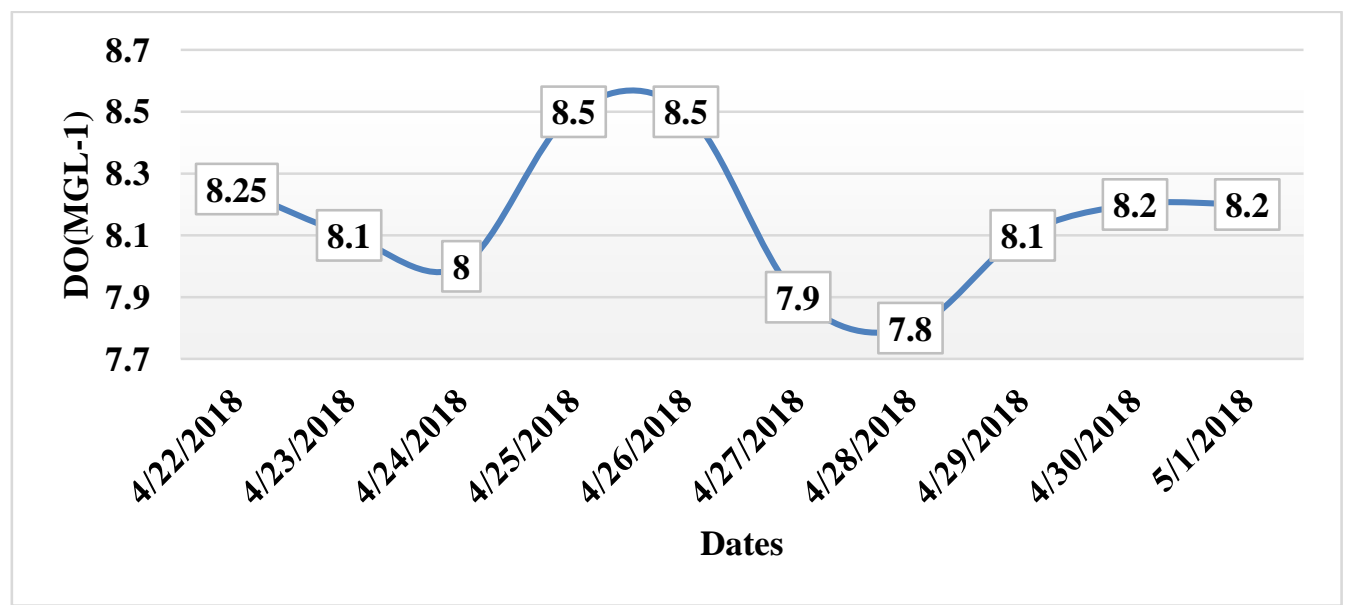

Figure 5. Dissolved Oxygen variation during mud crab fattening practice.

\subsection{Survival rate}

At the end of the experiment treatment 1 and treatment 3 were signified $100 \%$ survival rate while treatment 2 was $90 \%$ survival rate. Average survival rate was $96.67 \pm 5.77 \%$ (Table 3).

Table 3. Variation of survival rate $(\%)$ of crab among different treatments.

\begin{tabular}{|l|l|l|l|}
\hline Experiment & No. of stocked & No. of harvested & Survival rate (\%) \\
\hline Treatment 1 & 10 & 10 & 100 \\
\hline Treatment 2 & 10 & 9 & 90 \\
\hline Treatment 3 & 10 & 10 & 100 \\
\hline Average survival rate & & $96.67 \pm 5.77$ \\
\hline
\end{tabular}




\subsection{Growth performance}

In the present study, growth performance of female mud crab was being investigated against three treatments. The initial weight and final weight significantly different among the treatments $(\mathrm{P}<0.05)$ in this trial.

\subsubsection{Weight gain}

Average weight gain of mud crab (Scylla olivacea) fattening practice were $19.14 \pm 2.67 ; 13.29 \pm 2.03$ and 18.68 \pm 1.94 for treatment 1 , treatment 2 and treatment 3 respectively. Average weight gain was $17.04 \pm$ 3.25Treatment 1 (Chicken intestine) indicated highest average weight gain than other two feeds in crab fattening practice of 10 days (Figure 6).

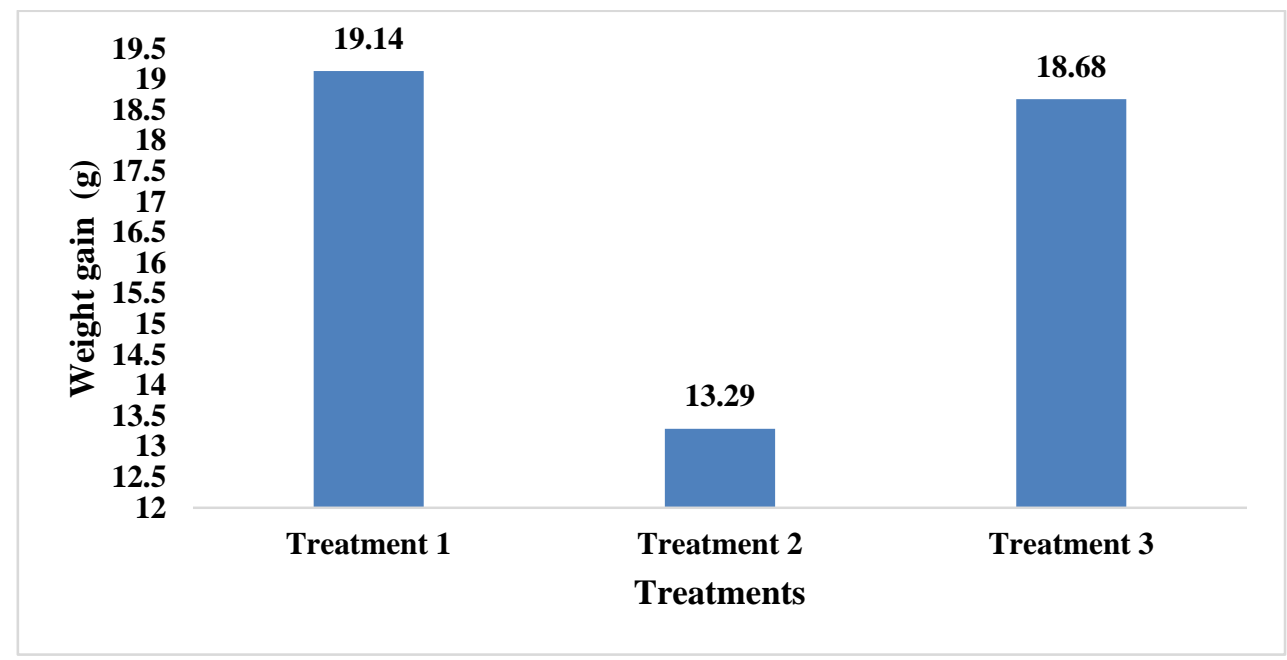

Figure 6. Variation of weight gain by different feeding trial.

\subsubsection{Weight gain percentage}

Weight gain percentage was observed and noted as 9.59\%; $6.78 \%$ and $8.89 \%$ for treatment 1 , treatment 2 and treatment 3 respectively. Average weight gain percentage $8.64 \pm 1.24 \%$. Treatment 1 (chicken intestine) exhibited highest percent weight gain (Figure 7).

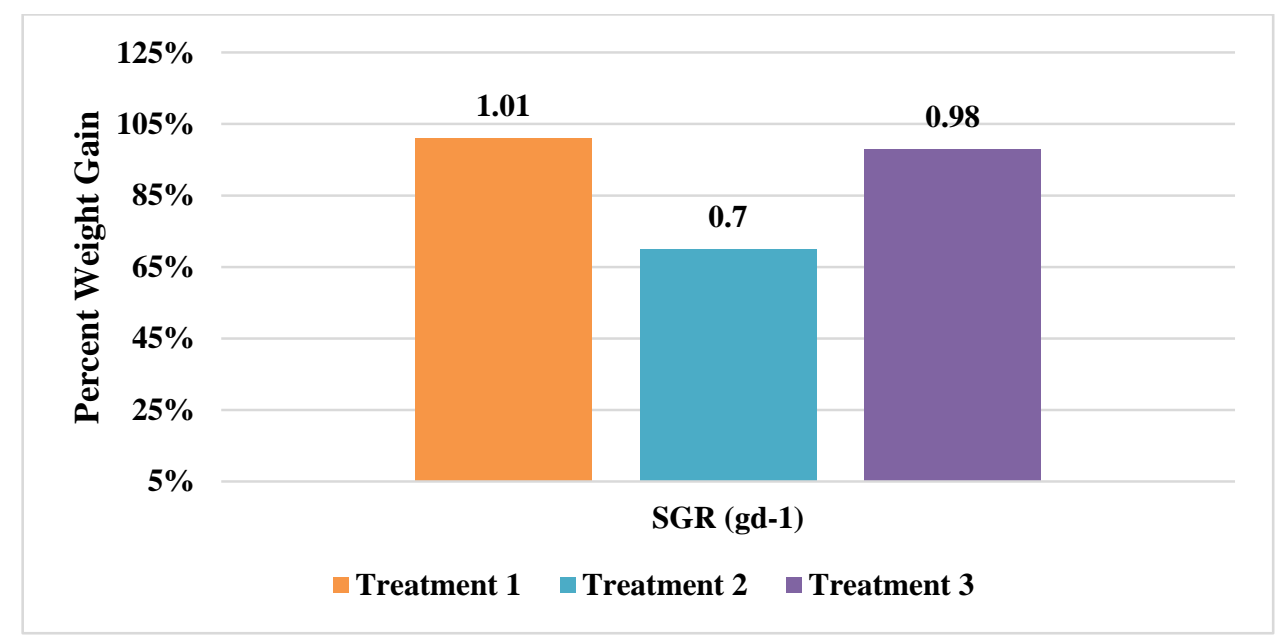

Figure 7.Variation of percent weight gain in different treatment.

\subsubsection{Growth rate}

Growth rate per day was recorded as following 1.91, 1.33 and 1.87 of treatment 1, treatment 2 and treatment 3 correspondingly. Among three feeding trial treatment 1 showed the highest growth rate $\left(1.91\right.$ gday $\left.^{-1}\right)$ and treatment 2 showed the lowest growth rate $\left(1.33\right.$ gday $\left.^{-1}\right)$. Average growth rate was recorded $1.70 \pm 0.32$ gday $^{-1}$ (Figure 8). 


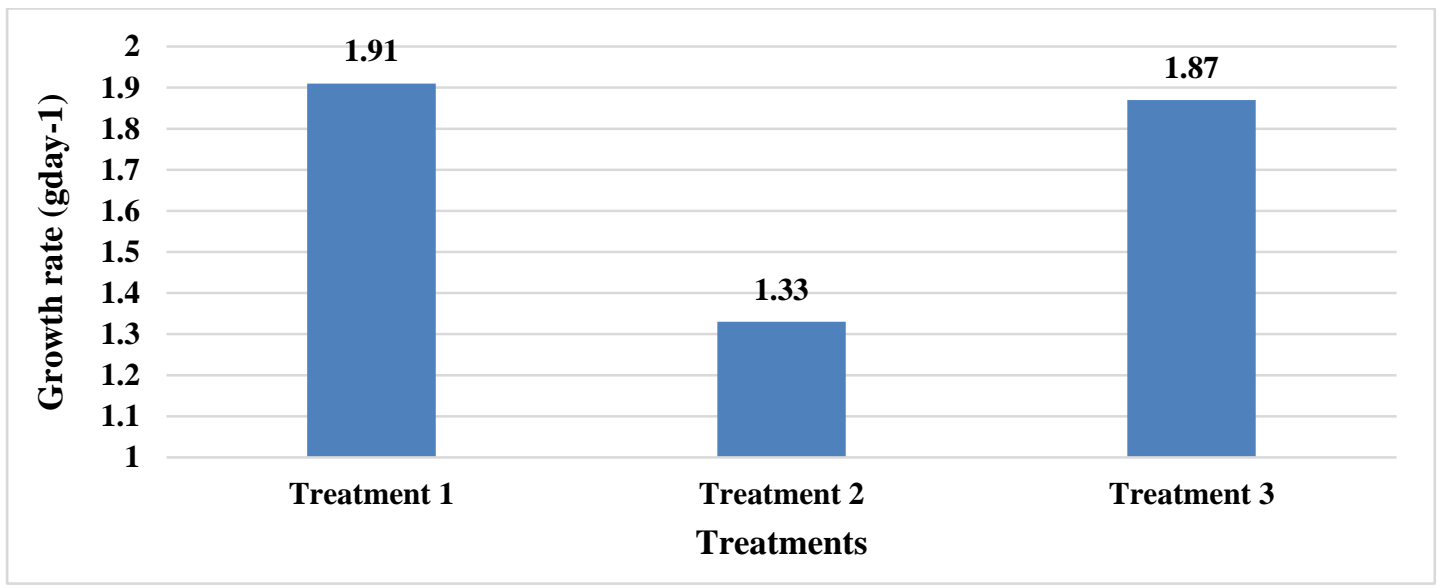

Figure 8. Variation of growth rate.

\subsubsection{Specific growth rate (SGR)}

There is no alteration in carapace length and carapace width was observed in initial and final stage (Table 4). As a result, specific growth rate of crab for carapace length or width (SGRCLW) was zero.

Table 4. Carapace length variation.

\begin{tabular}{|l|l|l|l|}
\hline Treatment types & $\begin{array}{l}\text { Minimum carapace } \\
\text { length }(\mathbf{m m})\end{array}$ & $\begin{array}{l}\text { Maximum carapace } \\
\text { length } \mathbf{( m m})\end{array}$ & $\begin{array}{l}\text { Average carapace length } \\
\mathbf{( \pm \mathbf { s d } )} \mathbf{( \mathbf { m m } )}\end{array}$ \\
\hline Treatment 1 & 83 & 115 & $100.45 \pm 9.01$ \\
\hline Treatment 2 & 89 & 109 & $100.20 \pm 6.37$ \\
\hline Treatment 3 & 108 & $99.60 \pm 5.67$ \\
\hline
\end{tabular}

\subsection{Total production}

In the experiment highest production $(1981.6 \mathrm{~g})$ was obtained from treatment 1 whither chicken intestine was used as diet. Treatment 2 where tilapia was used as diet showed lowest production (1739.88g). Average total production was $1897.16 \mathrm{~g}$ (Table 5).

Table 5. Variation of total production throughout different treatments.

\begin{tabular}{|l|l|l|l|}
\hline Kinds of treatment & Average final weight $(\mathbf{g})$ & No. of crab harvested & Total production (kg) \\
\hline Treatment 1 & $198.16 \pm 11.68$ & 10 & 19.82 \\
\hline Treatment 2 & $193.32 \pm 13.18$ & 9 & 17.40 \\
\hline Treatment 3 & $197.90 \pm 12.20$ & 10 & 19.70 \\
\hline Mean total production $(\mathrm{g})$ & & $18.98 \pm 1.36$ \\
\hline
\end{tabular}

\subsection{Feed utilization}

\subsubsection{Food conversion ratio (FCR)}

In the study FCR of the three treatments were obtained as 9.54; 13.90 and 9.90 for treatment 1 , treatment 2 and treatment 3 respectively. FCR was significantly higher in treatment 2 (tilapia) and treatment 1 (chicken intestine) exhibit lowest FCR (Figure 9). FCR was highly significant $(\mathrm{p}<.001)$ among the treatments.

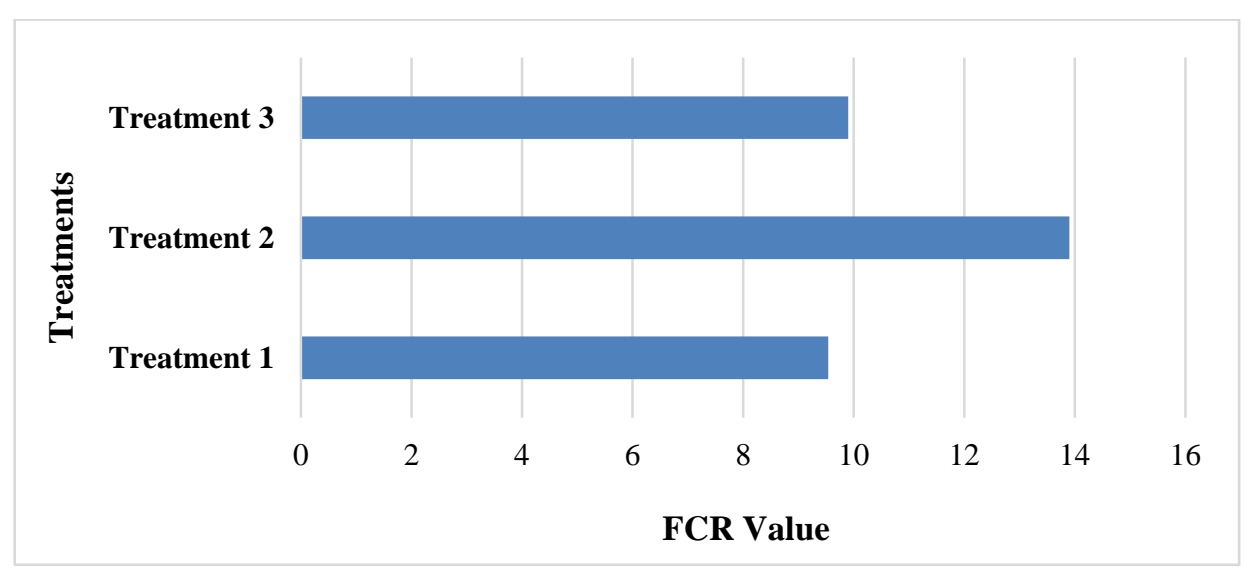

Figure 9. Variation in FCR for different feed. 
3.5.2. Food conversion efficiency (FCE)

FCE of the three treatments were obtained as $0.106 ; 0.073$ and 0.101 for treatment 1 , treatment 2 and treatment 3 respectively. FCE was significantly higher in treatment 1(chicken intestine) and treatment 2 (tilapia) showed lowest FCR (Table 6).

Table 6. Different FCE of different feed.

\begin{tabular}{|l|l|l|l|}
\hline Treatment types & Initial Weight $(\mathbf{g})$ & Final Weight $(\mathbf{g})$ & FCE \\
\hline Treatment 1 & $180.28 \pm 9.78$ & $198.16 \pm 11.68$ & $0.106 \pm 0.012$ \\
\hline Treatment 2 & $182.67 \pm 12.20$ & $195.96 \pm 13.37$ & $0.073 \pm 0.010$ \\
\hline Treatment 3 & $184.12 \pm 12.40$ & $203.01 \pm 14.02$ & $0.101 \pm 0.011$ \\
\hline Average FCE & & $0.0933 \pm 0.01$ \\
\hline
\end{tabular}

\subsection{Relationship between survival rate and production rate}

The statistical analysis showed that the production rate was significantly $(\mathrm{p}<0.05)$ correlated with survival rate. It was positively correlated at $0.05 \%$ significance level (Figure 10).

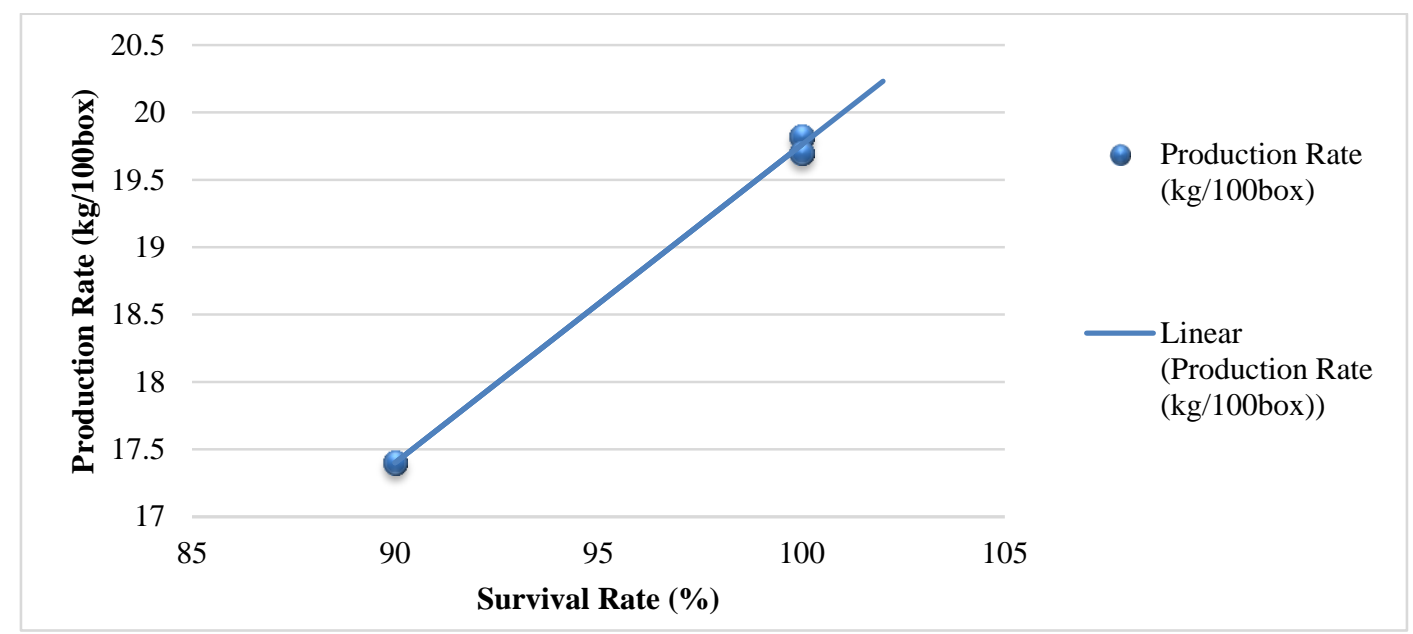

Figure 10. Relationship between survival rate and production rate.

\subsection{Relationship between SGR and FCR}

Specific Growth Rate was not significantly $(\mathrm{p}<0.05)$ correlated with feed conversion ratio. It was negatively correlated at $0.05 \%$ significance level (Figure 11 ).

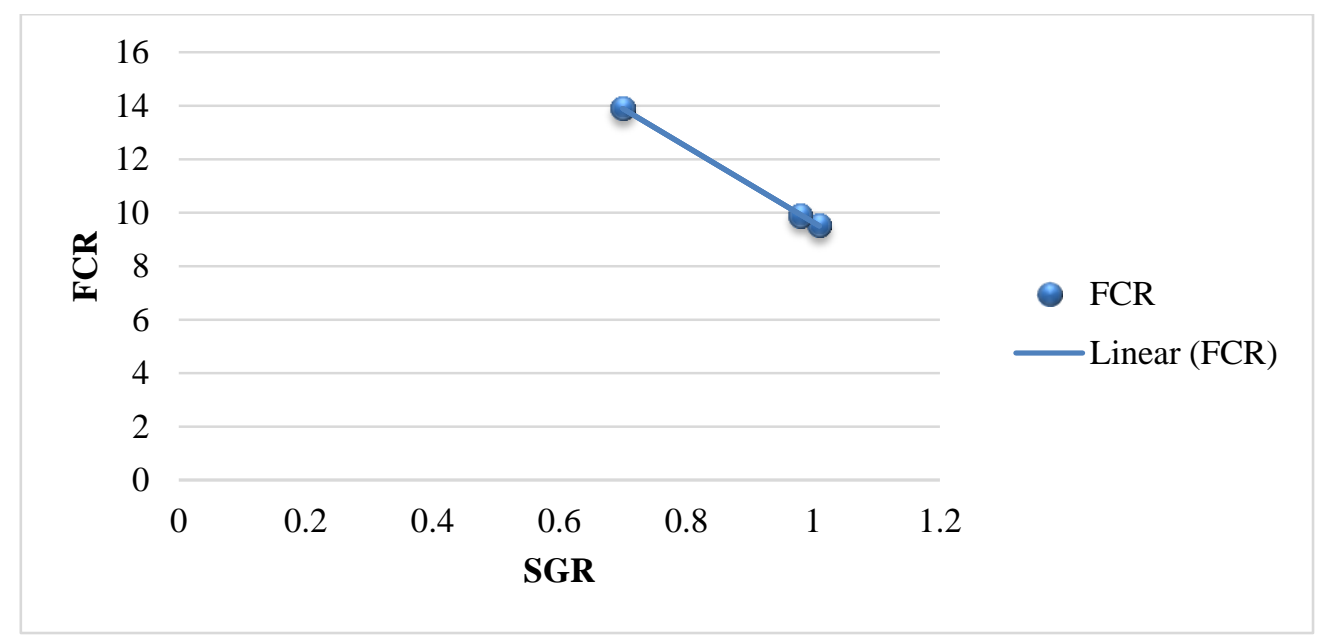

Figure 11. Relationship between SGR and FCR.

\subsection{Economic analysis}

Cost for crab fattening are categorized into two types: Capital cost or permanent cost and experimental cost or crop cost (Tables 7, 8 and 9; and Figure 12). 
Asian J. Med. Biol. Res. 2019, 5 (4)

Table 7. Cost and benefit of the female mud crab fattening for chicken intestine as feed.

\begin{tabular}{|c|c|c|c|c|}
\hline \multirow[t]{9}{*}{ Fixed Cost } & Items & Unit Cost & Quantity & Total Cost \\
\hline & Plastic box & 1 & 100 & 100 \\
\hline & PVC Pipe & 2.5 & 10 & 25 \\
\hline & Bamboo & 2.5 & 10 & 25 \\
\hline & Aluminum wire & - & - & 2 \\
\hline & Nylon wire & - & - & 1.5 \\
\hline & Basket & 1.5 & 1 & 1.5 \\
\hline & Others & - & - & 43 \\
\hline & & & & 198 \\
\hline \multirow[t]{6}{*}{ b. Operational Cost } & $\begin{array}{l}\text { Immature female mud } \\
\text { crab }\end{array}$ & 1.25 & 100 & 125 \\
\hline & Feed (chicken intestine) & 0.138 & $18 \mathrm{~kg}$ & 2.5 \\
\hline & Labor cost & & & 11 \\
\hline & Transport cost & & & 1 \\
\hline & Depreciation of fixed cost & & & 12.5 \\
\hline & & & & 152 \\
\hline \multirow[t]{2}{*}{ Gross Income } & Items & Unit Price & Quantity & Total Price \\
\hline & Mature mud crab & 12 & $19.94 \mathrm{~kg}$ & 239 \\
\hline Net Benefit & $\mathrm{b}-\mathrm{c}$ & \multicolumn{2}{|l|}{$239-152$} & 87 \\
\hline Benefit Cost Ratio & $\mathrm{c} / \mathrm{b}$ & \multicolumn{2}{|l|}{$87 / 152$} & 0.57 \\
\hline
\end{tabular}

Table 8. Cost and benefit of the female mud crab fattening for Tilapia fish as feed.

\begin{tabular}{|c|c|c|c|c|}
\hline \multirow[t]{9}{*}{ Fixed Cost } & Items & Unit Cost & Quantity & Total Cost \\
\hline & Plastic box & 1 & 100 & 100 \\
\hline & PVC Pipe & 2.5 & 10 & 25 \\
\hline & Bamboo & 2.5 & 10 & 25 \\
\hline & Aluminum wire & - & - & 2 \\
\hline & Nylon wire & - & - & 1.5 \\
\hline & Basket & 1.5 & 1 & 1.5 \\
\hline & Others & - & - & 43 \\
\hline & & & & 198 \\
\hline \multirow[t]{6}{*}{ B. Operational cost } & $\begin{array}{l}\text { Immature female mud } \\
\text { crab }\end{array}$ & 1.25 & 100 & 125 \\
\hline & Feed (tilapia fish) & 0.355 & $18.2 \mathrm{~kg}$ & 6.5 \\
\hline & Labor cost & & & 11 \\
\hline & Transport cost & & & 1 \\
\hline & Depreciation of fixed cost & & & 12.5 \\
\hline & & & & 156 \\
\hline \multirow[t]{2}{*}{ Gross Income } & Items & Unit Price & Quantity & Total Price \\
\hline & Mature mud crab & 12 & $17.58 \mathrm{~kg}$ & 211 \\
\hline Net Benefit & $b-c$ & \multicolumn{2}{|l|}{$211-156$} & 55 \\
\hline Benefit Cost Ratio & $\mathrm{c} / \mathrm{b}$ & \multicolumn{2}{|l|}{$55 / 156$} & 0.33 \\
\hline
\end{tabular}


Table 9. Cost and benefit of the female mud crab fattening for apple snail as feed.

\begin{tabular}{|c|c|c|c|c|}
\hline \multirow[t]{9}{*}{ Fixed Cost } & Items & Unit Cost & Quantity & Total Cost (USD) \\
\hline & Plastic box & 1 & 100 & 100 \\
\hline & PVC Pipe & 2.5 & 10 & 25 \\
\hline & Bamboo & 2.5 & 10 & 25 \\
\hline & Aluminum wire & - & - & 2 \\
\hline & Nylon wire & - & - & 1.5 \\
\hline & Basket & 1.5 & 1 & 1.5 \\
\hline & Others & - & - & 43 \\
\hline & & & & 198 \\
\hline \multirow[t]{6}{*}{ b. Operational Cost } & $\begin{array}{l}\text { Immature female } \\
\text { mud crab }\end{array}$ & 1.25 & 100 & 125 \\
\hline & Feed (apple snail) & 0.556 & $18.4 \mathrm{~kg}$ & 10.25 \\
\hline & Labor cost & & & 11 \\
\hline & Transport cost & & & 6.25 \\
\hline & $\begin{array}{l}\text { Depreciation of fixed } \\
\text { cost }\end{array}$ & & & 12.5 \\
\hline & & & & 165 \\
\hline \multirow[t]{2}{*}{ Gross Income } & Items & Unit Price & Quantity & Total Price \\
\hline & Mature mud crab & 12 & $20.27 \mathrm{~kg}$ & 243 \\
\hline Net Benefit & $\mathrm{b}-\mathrm{c}$ & \multicolumn{2}{|l|}{$243-165$} & 78 \\
\hline Benefit Cost Ratio & $\mathrm{c} / \mathrm{b}$ & \multicolumn{2}{|l|}{$78 / 165$} & 0.47 \\
\hline
\end{tabular}

Use of Chicken intestine as feed for mud crab fattening practice provided more revenue than rest two other feed.

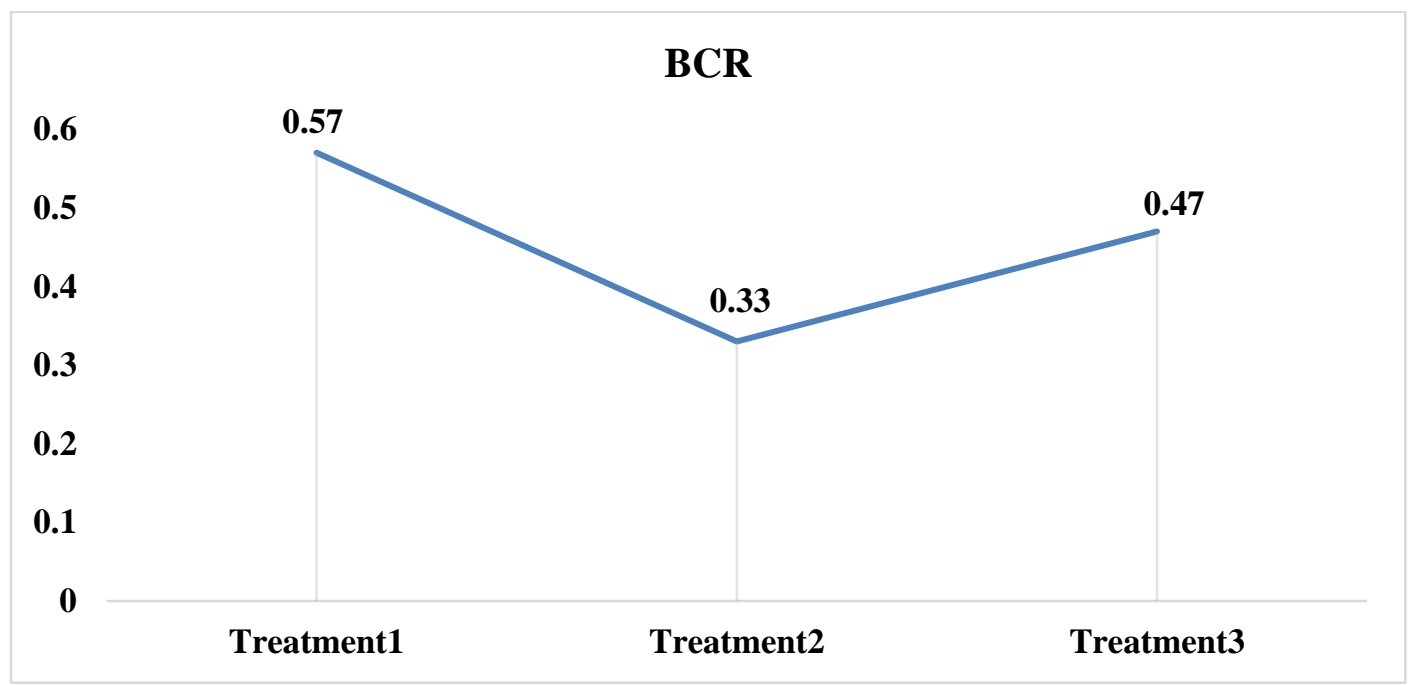

Figure 12. Variation of BCR for different feeds.

\section{Discussion}

Optimum water quality parameters for crab growth such as salinity range from $10-35 \mathrm{ppt}$, temperature $21-35^{\circ} \mathrm{C}$, pH 4-9 and DO over 4 reported by Cholik and Hanafi (1992). Growth of crab is reduced below $20^{\circ} \mathrm{C}$ (Hill, 1980). The water quality parameters for crab fattening were reported by Begum et al., (2009) salinity, 10-18 ppt; temperature: $26-31^{\circ} \mathrm{C} ; \mathrm{pH}, 7.5-8.7$ and dissolved oxygen, 4.0-7.9 $\mathrm{mg} / \mathrm{l}$. In the experiment water parameters, such as $\mathrm{pH}$, temperature, salinity and $\mathrm{DO}$ were varied from 7.7-8.1 28.4-32. $7^{\circ} \mathrm{C}, 17.1-19.3 \mathrm{ppt}$ and 7.7-8.3 mg/L respectively which is acceptable range for crab fattening according to Cholik and Hanafi (1992) and showed similarity with Begum et al., (2009). The water quality management is also supported by the study of different researcher (Ali et al., 2016; Shabuj et al., 2016;Shajib et al., 2017; Zafar et al., 2017; Rahman et al., 2018; Akter et al., 2018; Faruk et al., 2018; Biswas et al., 2018; Billah et al., 2019).In the present experiment, $100 \%$ survival was obtained for crabs fed with Chicken intestine and Apple snail meat. The other feeds had lower survival rate and it was $90 \%$. The survival rate was not only accredited to the diets but also to the rearing condition (i.e. water quality, management). This observation settled with what has been noted by Baliao et al. (1981) and Trino et al. (1999), who reported survival rates of $88 \%$ and $98 \%$, respectively, at a low stocking 
density of 0.5 crabs per $\mathrm{m}^{2}$. Also Sheen and $\mathrm{Wu}$ (1999) had a survival of 93-100\% after 63 days using purified diets and reared individually. In the present study, survival was also enhanced by proper feeding and management. Major cause of mud crab mortality during fattening of mud crab is cannibalism (Mirera and Moksens, 2013). No cannibalism occurred in this experiment occur in this experiment as each crab was kept in a separate plastic box. Average weight gain of mud crab (Scylla Olivacea) fattening practice was found in the experiment $17.04 \pm 3.25 \mathrm{~g}$ and which is near to Begum et al., (2009) $(16.24 \pm 0.85 \mathrm{~g})$. Growth rate per day of Scylla Serrata was recorded 1.91, 1.33 and 1.87 for the treatment 1, treatment 2 and treatment 3. Average growth rate was $1.70 \pm 0.32 \mathrm{~g} /$ day. The result has similarity with the findings of Zafar and Ahsan (2006) and Obayed (1998) who recorded 1.89-1.95 g/day. Specific growth rate was highest in mud crab fed with chicken intestine and it was $1.01 \%$ day $^{-1}$. Tilapia fish and golden apple snail were showed $0.70 \%$ day $^{-1}$ and $0.98 \%$ day $^{-1}$. Rabia (2016) reported that specific growth rate was highest in mud crab fed with golden apple snails and combination of trash fish and golden apple snails at both $1.54 \%$ day $^{-1}$. Average Specific growth rate of mud crab in all the treatments was $1.70 \pm 0.32 \%$ day $^{-1}$ and which was comparable to that of mixed sex mud crab reared in ponds fed with trash fish for 20 days with specific growth rate of $0.8+0.12 \%$ day $^{-1}$ (Trino and Rodriguez, 2001). In the present study production of the crabs were $19.82 \mathrm{~kg}, 17.40 \mathrm{~kg}$ and $19.70 \mathrm{~kg}$ for the treatment 1 , treatment 2 and treatment 3. Average production of crab was $18.97 \mathrm{~kg}$ which is near to Rahman (2016). This production rate may be considered good for crab fattening in the plastic box. Significantly higher FCR was observed in Treatment two. FCR was higher in tilapia than other foods. Higher FCR indicated low growth as SGR is inversely related to FCR. Specific growth rate for weight $S_{G} R_{W}$ varied significantly among the treatment. Treatment 1 and Treatment 3 showed comparatively higher growth rate. Statistical analysis indicated that better growth rate was observed in Chicken intestine compared with tilapia and apple snail meat. This result is similar to the findings of Rodriguez et al. (2003). The boxes that were used was collected from collection of the farmer. However, he made these boxes by creating holes in color boxes. Each box costs 80 takas including the labor cost. Each of the box can be used for 20 cycle so cost of box per culture is very low. In this study, locally available low cost chicken intestine, tilapia fish (O. mossambicus), aplle snail (Pila globosa) were used as feed. The earlier studies on the food and feeding of Scylla sp. Hill (1976); Prasad and Neelakantan (1988); Joel and Raj (1983) were used crustaceans, molluscs, fishes etc. Commonly available low cost trash fishes were the main feed used in crab fattening by Rattanachote and Dangwatanakul, (1992). According to the report of Zafar and Ahsan (2006), farmers usually applied the feed at the rate of 5 to $8 \%$ of the body weight. Chilok and Hanafi (1992) were used $10-15 \%$ of body weight feed rate in every day to reduce the mortality and increased the survival rate up to 85 to $90 \%$. The statistical analysis showed that the correlation coefficient ' $r$ ' was 0.999 which was near to +1 . So the production rate was positively correlated with survival rate that meant when survival rate increased production rate also increased. Specific growth rate was not significantly $(p<0.05)$ correlated with feed conversion ratio. Correlation coefficient ' $r$ ' was -1 so there was negatively correlation between FCR and SGR that meant when FCR increased SGR decreased. The revenue that is gained from the experiment is significantly higher than the other two feeds. Revenue that is gained from mud crab treated with snail and tilapia did not varied significantly. The present study showed that chicken intestine could be alternative inexpensive feed for mud crab with higher growth and economic performance and it was comparable to Chilok and Hanafi (1992) and Rahman et al. (2017). Rabia (2016) reported that Mud crab fed with golden apple snail constitute the high return of investment compared to the other treatments as indicated that low expenses incurred during the conduct of the study because feeds are readily available and this statement was similar for the current experiment where chicken intestine provided highest return .

\section{Conclusions}

Present study indicates the utilization of waste as feed for crab fattening practice and reveal potentiality of chicken intestine. From the results of this study, it may be concluded that usage of chicken intestine as feed for fattening of mud crab in plastic box might be better than that of tilapia or apple snail meat as feed. This result might be helpful to reduce the traditional fattening method and motivate the people to adopt the scientific method as well as introducing inexpensive feed. Economic analysis from the present study showed that female mud crab fattening in plastic box can be economically viable through its higher profitability with low cost of investment. Further studies should be done to analyze the quality of meat of crab by feeding chicken intestine as feed and effect of this by product on human health.

\section{Conflict of interest}

None to declare. 


\section{References}

Akter S, MM Rahman, A Faruk, MNM Bhuiyan, A Hossain and AA Asif, 2018. Qualitative and quantitative analysis of phytoplankton in culture pond of Noakhali district, Bangladesh. Int. J. Fish. Aqua. Stud., 6: 371375.

Ali MM, AA Asif, MAI Shabuj, S Vaumik, MA Zafar and BMN Sharif, 2016. Status of polyculture Pangasius hypophthalmus with carps in Jhikargacha Upazila of Jessore District, Bangladesh. Int. J. Fish. Aqua. Stud., 4: 423-430.

Anon, 2003. Potentiality for the Development of a Mollusk Fishery in Coastal Bangladesh, Concept Note (February), SUFER Project, DFID, Bangladesh.

Asif AA, MA Samad, BMS Rahman, MA Rahman, MH Rahman, SM Yeasmin, and A Nima, 2014. Study on Management of Fish Fry and Fingerling Marketing of Jessore in Bangladesh. Int. J. Bus. Soc. Sci. Res., 2: 127-135.

Baliao DD, MADL Santosand and NN Franco, 1999. Pen culture of mud crab in mangroves. Aquacul. Ext. Maul., No.29, March (1999). pp. 10.

Begum M, Shah MMR, Mamun AA, and Alam MJ, 2009. Comparative study of mud crab (Scylla serrata) fattening practices between two different systems in Bangladesh. J. Bangladesh Agric. Univ., 7: 151-156.

Billah MM, MK Uddin, MYA Samad, MZB Hassan, MP Anwar, AHM Kamal, M Shahjahan and AA Asif, 2019. Fertilization effects on the growth of common carp (Cyprinus carpio) and Nile tilapia (Oreochromis niloticus) and rice yields in an integrated rice-fish farming system. AACL Bioflux, 12:121-132.

Biswas C, MMM Hossain, AA Asif, B Sarker, MM Billah and MA Ali, 2018. Culture strategies, diseases and their mitigations in mono-sex Nile tilapia farming in Jessore sadar region, Bangladesh. Asian Australas. J. Biosci. Biotechnol., 3:190-200.

Chandra KJ, AK Paul, DR Das, 2012. A survey on the production and marketing of mud crab, Scylla serrata (Forskal, 1755) in the south-western part of Bangladesh. IRJALS, 1:44-55.

Cholik F and A Hanafi, 1992. A review of the status of the mud crab (Scylla sp.) fishery and culture in Indonesia. In Report of the seminar on mud crab culture and trade. Bay of Bengal Programme, Madras. BOBP/REP/51, pp. 13-27.

De Silva SS and TA Anderson, 1995. Fish Nutrition in Aquaculture. Chapman and Hall Aquaculture Series, London, pp.319.

Faruk A, A Hossain, AA Asif, MNM Bhuiyan and MJ Sarker, 2018. Culture and management techniques of Vietnamese Koi. Asian Australas. J. Biosci. Biotechnol., 3: 93-105.

Hill BJ, 1976. Natural food, foregut clearance-rate and activity of the crab Scylla serrata. Mar. Biol., 34: 109116.

Hill BJ, 1980. Aspects of the feeding strategy of the predatory crab Scylla serrata. Mar. Biol., 55: 209-214.

Hoque MM, MK AbuHena, MH Idris, OH Ahmed, ASM Saifullah and MM Billah, 2015. Status of some fishery resources in a tropical mangrove estuary of Sarawak, Malaysia. Mar. Biol.Res., 11: 834-846.

Hossain MA, AA Asif, MA Zafar, MT Hossain, MS Alam and MA Islam, 2015. Marketing of fish and fishery products in Dinajpur and livelihoods of the fish retailers. Int. J. Fish. Aqua. Stud., 3: 86-92.

Hossain MD, A Hossain, H Rahman, M Rahman, AA Asif, MM Billah and MAI Mondal, 2018. Marketing channels of mud crab (Scylla serrata) at Nijhum Dwip, Noakhali, Bangladesh: A value chain analysis. J. Ento. Zool. Stud., 6: 521-527.

Islam MS, AA Asif, B Sarker, A Satter, M Ahmed, M Rahman, MA Zafar and SM Rahmatullah, 2017. Fry production and its marketing system of North-West fisheries extension project at Parbatipur, Dinajpur, Bangladesh. Asian J. Med. Biol. Res., 3: 368-378.

Joel DR and PS Raj, 1983. Taxonomic remarks on two species of the genus Scylla de Haan (Portunidae: Brachyura) from Pulicat Lake. Indian J. Fish., 30: 13-26.

Kaleem S, MK AbuHena, A Daud, R Zamri, RH Khalid and MN Hoque, 2016. Community awareness about tangible and intangible benefits of Sibuti mangrove forest, Sarawak, Malaysia. Malaysian Fores., 79:119132.

Keenan CP, 1999. The fourth species of Scylla. In ACIAR proceedings. Australian Cen. Int. Agri., 48-58.

Leela M, MFU Zaman, AA Asif and MA Hossain, 2018. Availability of fish species in fish markets and fish marketing in Noakhali district, Bangladesh. J. Ento. Zool. Stud., 6: 1332-1344.

Mirera OD and PO Moksnes, 2013. Cannibalistic Interactions of Juvenile Mud Crabs (Scylla serrate: Forsskal, 1775): The effect of shelter and crab size. African J. Mar. Sci., 35: 545-553.

Obayed S, 1998. Study on the culture and fattening of the mud crab Scylla serrata (Forskal) in the great Khulna region. M.Sc. Thesis. Institute of Marine Science University of Chittagong. Chittagong Bangladesh, pp. 87. 
Prasad PN and B Neelakantan, 1988. Food and feeding of the mud crab Scylla serrat Forskal (Decapoda: Portunidae) from Karwar waters. Indian J. Fish., 35: 164-170.

Rabia MDS, 2016. Length and Weight Characteristics of Mud Crab (Scylla serrata) Fed with Indigenous Feeds in Plastic Container. Env. Sci., 4: 53 - 61.

Rahaman MM, MA Zafar, BMN Sharif, P Paul, AA Asif, MM Islam and MI Hossain, 2015. Tilapia (Oreochromis mossambicus) marketing system in greater Jessore region, Bangladesh. Int. J. Fish. Aqua. Stud., 3: 95-103.

Rahman H, JA Mirza, A Hossain, AA Asif, E Haq, P Chwakravorty and M Rahman, 2017. Economics of fish production in paddy fields in Bangladesh. Asian J. Med. Biol. Res., $3: 379-390$.

Rahman MM, 2016. Small-scale mud crab Scylla sp. fattening in Shyam-nagar, Satkhira. Bangladesh J. Zool., 44:163-166.

Rahman MM, MMM Hossain, MM Billah, AA Asif and J Ferdous, 2018. Growth of freshwater mud eel (Monopterus cuchia) in different water condition, feeds and probiotics. Int. J. Bus. Soc. Sci. Res., 7: 10-17.

Rattanachote A and R Dangwatanakul, 1992. In: Angell, C.A. (Ed.) Report of seminar on the mud crab culture and Trade held at Surat Thani, Thailand, November, 5-8, 1991. Bay of Bengal program, BOBP/Rep/51, Madras, India, pp.171-177.

Rodriguez EM, Trino AT, and Minagawa M 2003. Diet and harvesting regimen for the production of mud crab Scylla olivacea in brackish water ponds. Fish. Sci., 69: 37-42.

Shabuj MAI, T Bairagi, AA Asif, O Faruq, MR Bari and MS Neowajh, 2016. Shrimp disease investigation and culture strategies in Bagerhat district, Bangladesh. Asian J. Med. Biol. Res., 1: 545-552.

Shajib MSH, B Sarker, AA Asif, MM Rahman, MA Zafar and A Hossain, 2017. Effects of stocking density on the growth rate of gold fish fry reared in hapa. Asian J. Med. Biol. Res., 3: 504-515.

Sheen S and S Wu, 1999. The effects of dietary lipid levels on the growth response of juvenile mud crab Scylla serrata. Aquaculture, 175: 143 - 153.

Trino AT and EM Rodriguez, 2001. Mud crab fattening in ponds. Asian Fish. Sci., 14: 211-216.

Trino AT, OM Millamena and CP Keenan, 1999. Pond culture of the mud crab Scylla serrata (Forskal) fed formulated diet with or without vitamin and mineral supplements. Asian Fish. Sci., 14: 191-200.

Zafar M and MN Ahsan, 2006. Marketing and value chain analysis of mud crab (Scylla sp.) in the coastal communities of Bangladesh. In value chain analysis and market assessment of coastal and marine aquatic products of Bangladesh. Bangladesh Fisheries Research Forum, Dhaka, pp. 25-53.

Zafar MA, MZ Hasan, MM Ali and AA Asif, 2017. Growth and production performance of Vietnamese koi (Anabas testudineus) with Magur (Clarias batrachus) at different stocking densities. Asian Australas. J. Biosci. Biotechnol., 2: 226-237. 